\title{
APLIKASI TARIF PELAYANAN JASA METEOROLOGI BERBASIS CLIENT SERVER
}

\author{
Yusri Ikhwani, S.Kom., M.Kom. \\ (yusri@fti.uniska-bjm.ac.id) \\ Mayang Sari, S.Kom., M.Kom. \\ (mayang@fti.uniska-bjm.ac.id) \\ Wahyudi Fajar Persada, S.Kom. \\ (wahyudi.f.persada@gmail.com)
}

\begin{abstract}
ABSTRAK
Badan Meteorologi, Klimatologi dan Geofisika, Stasiun Meteorologi Beringin Muara Teweh Kalimantan Tengah, melakukan proses pelayanan tarif jasa meteorologi secara manual sehingga mengakibatkan keterlambatan dalam pemprosesan data, serta pencarian informasi yang diinginkan, tidak efisien dan tidak aman dalam penyimpanan data yang menyangkut dengan tarif pelayanan jasa meteorologi.

Aplikasi Tarif Pelayanan Jasa Meteorologi Berbasis Client Server dibuat agar mempermudah bagian pelayanan dan bendahara dalam hal pekerjaan pelayanan jasa tarif meterologi, staf pengolah data dapat memperoleh informasi yang cepat dan akurat. Adanya Aplikasi Tarif Pelayanann Jasa Meteorologi Berbasis Client Server dapat meningkatkan pelayanan Stasiun Meteorologi Beringin Muara Teweh dalam hal pelayanan jasa meteorologi.

Dalam pembuatan aplikasi ini, peneliti menggunakan tool Borland Delphi 7, adapun database yang digunakan adalah Mysql serta menggunakan service xampp.

Dengan menggunakan aplikasi tarif pelayanan jasa meteorologi ini, memberikan kemudahan dalam pelayanan jasa meteorologi, menghasilkan laporan dan informasi yang akurat dan teliti, menjamin keamanan data dan meningkatkan pelayanan Stasiun Meteorologi Beringin Muara Teweh Kalimantan Tengah terhadap pelayanan jasa meteorologi.
\end{abstract}

Kata Kunci : Aplikasi, Tarif Pelayanan Jasa Meteorologi, Delphi 7

\section{PENDAHULUAN}

Kehidupan manusia saat ini dihadapkan pada kemajuan teknologi yang terus berubah dan mengalami perkembangan dengan begitu cepat. Salah satu hasil perkembangan teknologi adalah komputer sebagai alat bantu manusia yang memiliki kelebihan diantaranya kecepatan, keakuratan serta efisiensi pekerjaan terutama digunakan dalam melakukan input data, proses hingga menyajikan informasi bagi penggunanya berupa laporan-laporan yang akan dijadikan sebagai bahan dalam mengambil keputusan.

Stasiun Meteorologi
Muara Teweh Kalimantan $\begin{array}{r}\text { Tengah } \\ \text { merupakan tempat melakukan penelitian, }\end{array}$
Stasiun Meteorologi Beringin Muara
Teweh Kalimantan Tengah pada bagian
pelayanan memiliki tugas pokok salah
satunya adalah menyelenggarakan kegiatan
pelayanan terhadap tarif jasa meterologi
baik itu untuk konsultasi maupun untuk
tujuan komersil.
Bagian pelayanan pada Stasiun
Meterologi Beringin Muara Teweh
Kalimantan Tengah masih melakukan
pelayanan jasa tarif meterologi secara
manual yaitu dengan cara mendata


permohonan pelanggan terhadap tarif jasa meterologi di sebuah buku pendataan. Bagian bendahara juga berperan dalam sistem ini yaitu melakukan perhitungan terhadap jasa tarif yang di butuhkan oleh pemohon namun perhitungan tersebut masih di lakukan dengan cara manual. Sistem yang masih manual dan tidak adanya keterhubungan sistem di dua bagian ini mengakibatkan terjadinya keterlambatan terhadap pemrosesan data, keterlambatan dalam pemberian informasi kepada staf pengolah data, tidak efisien, kurang aman dan menyulitkan dalam pencarian informasi yang diinginkan.

\section{RUMUSAN MASALAH}

Berdasarkan uraian masalah yang telah dideskripsikan di atas maka rumusan masalah dari penelitian ini Bagaimana membuat sistem yang dapat menjamin keamanan data dan dapat mempercepat pemrosesan data, serta mempercepat dalam mencari informasi yang diinginkan.

\section{TUJUAN PENELITIAN}

Tujuan dari penelitian ini adalah menganalisa, merancang dan membuat aplikasi tarif pelayanan jasa meteorologi berbasis client server pada stasiun meteorologi beringin muara teweh Kalimantan tengah.

\section{TARGET LUARAN DAN MANFAAT PENELITIAN}

Target luaran dalam pembuatan penelitian ini adalah untuk meningkatkan pelayanan di Stasiun Meteorologi Beringin Muara Teweh Kalimantan Tengah dalam hal pelayanan jasa meterologi.

\section{METODE PENELITIAN}

Langkah-langkah yang dilakukan dalam pembuatan perangkat lunak ini antara lain :

\section{Analisis Kebutuhan Sistem}

Dalam proses ini dilakukan pengumpulan data baik secara observasi, studi literature dan wawancara untuk menganalisa kebutuhan penggguna, analisis kebutuhan fungsional sistem, analisis kebutuhan hardware dan software pada sistem yang akan dibangun.

\section{Desain Sistem}

Melakukan perancangan terhadap sistem berdasarkan analisis kebutuhan seperti rancangan model sistem, rancangan basis data, rancangan antar muka masukan sistem (input) dan rancangan antar muka luaran sistem (output)

\section{Pembuatan Coding dan Testing}

Tahapan ini merupakan tahap pengkodean (coding) untuk membangun aplikasi secara utuh. Setelah proses pengkodean (coding) selesai selanjutnya proses pengujian dilakukan. Pengujian aplikasi bertujuan untuk mengetahui kesalahan-kesalahan yang mungkin terjadi jika aplikasi telah digunakan.

\section{Implementasi}

Implementasi dilakukan setelah aplikasi lolos uji ketika dilakuan pengujian (testing). Perangkat yang diperlukan untuk implementasi adalah hardware komputer, dan juga di dukungan seperti kebijakan, prosedur, pelatihan pengguna, dan sebagainya.

\section{ANALISIS DAN PEMBAHASAN SISTEM}

\section{Analisis Sistem yang berjalan}

Sistem pelayanan yang sedang berjalan atau yang masih diterapkan di Badan Meteorologi Klimatologi dan Geofisika digambarkan dalam flowmap: 


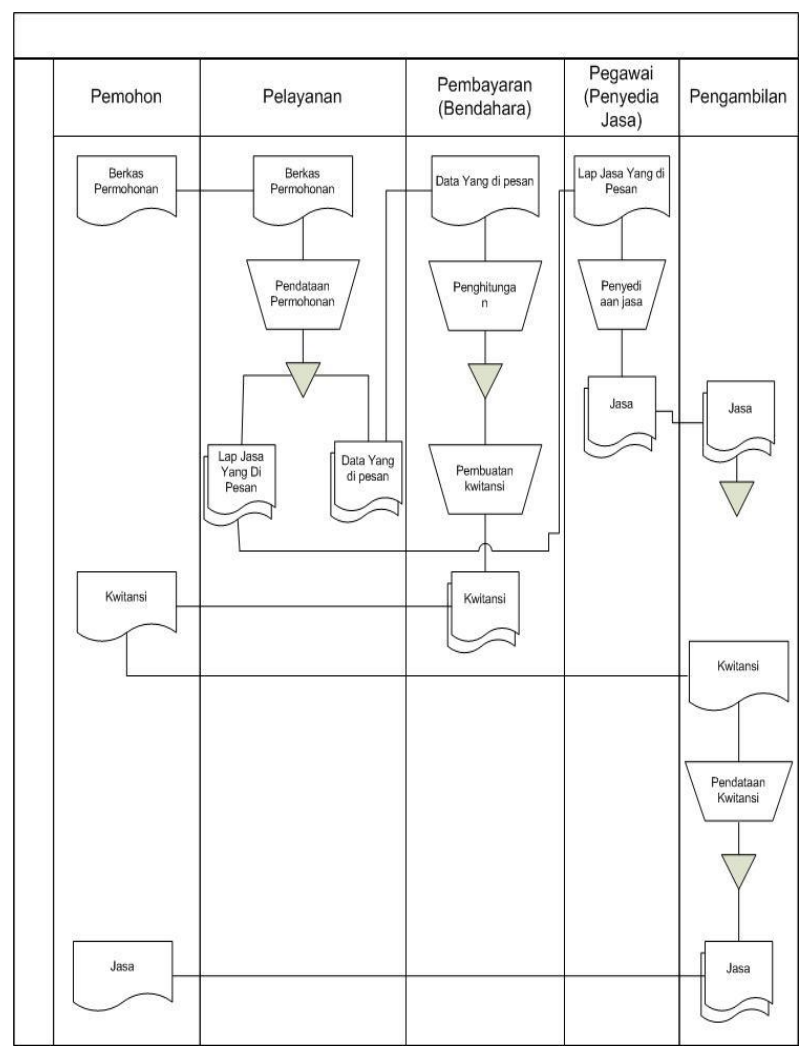

\section{Analisis Sistem Yang di Usulkan}

Sistem pelayanan yang diusulkan atau yang ingin diterapkan di Badan Meteorologi Klimatologi dan Geofisika digambarkan dalam flowmap:

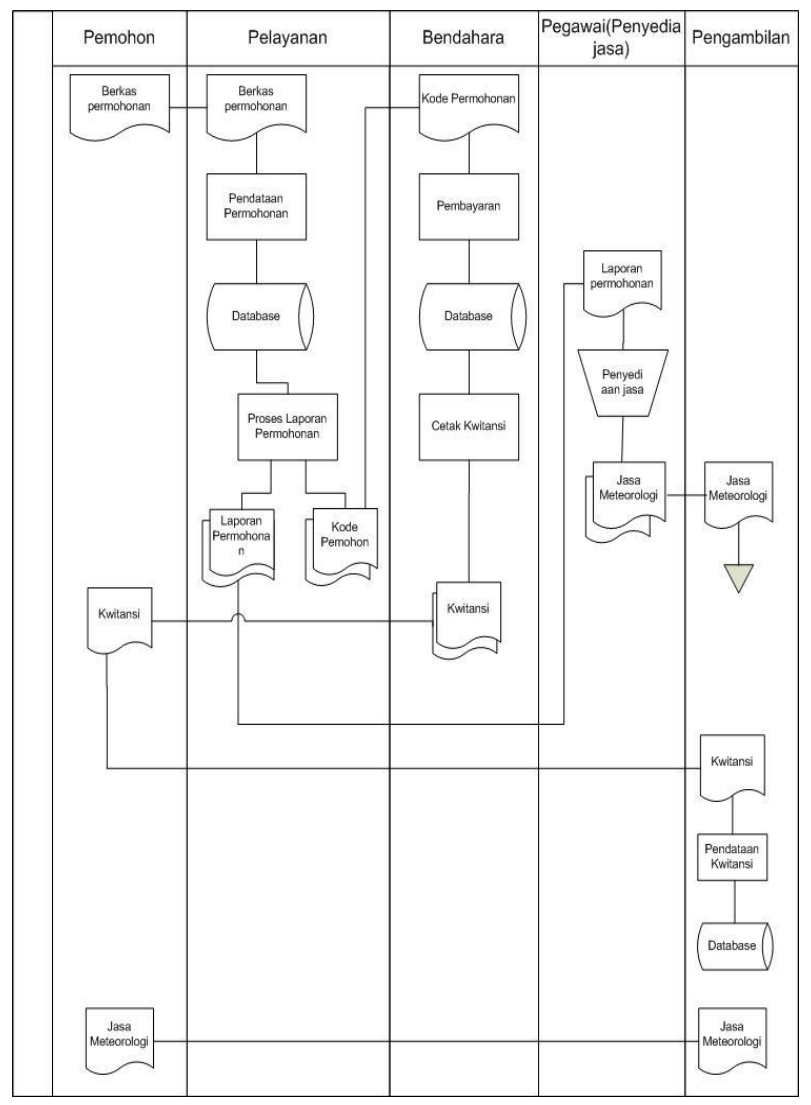

Jurnal Ilmiah Fakultas Teknik "Technologia”

\section{Analisis Kebutuhan Sistem}

Implementasi sistem program ini mencakup spesifikasi kebutuhan perangkat keras (hardware) dan spesifikasi perangkat lunak (software).

\section{Spesifikasi Perangkat Keras dan Perangkat Lunak}

Program ini direkomendasikan untuk dijalankan dengan menggunakan perangkat keras (hardware) yang mempunyai spesifikasi berikut:

- Komputer atau Laptop Prosesor Minimal Intel core i3 atau AMD Llano seri A3.

- RAM minimal $1 \mathrm{~GB}$.

- Harddisk minimal 320 GB.

- Monitor dengan resolusi $1024 \times 768$ pixel.

- Keyboard dan Mouse.

Adapun perangkat lunak (software) yang digunakan untuk menjalankan aplikasi ini adalah SO Windows 7, tool Delphi dan Database MySql.

\section{Rancangan Model Sistem}

Rancanan model sistem aplikasi tarif pelayanan jasa meteorologi berbasis client server adalah sebagai berikut:

\section{- Client Server}

Aplikasi tarif pelayanan jasa meteorologi menggunakan sistem yang berbasis client server dan sms gateway. Client server adalah suatu bentuk arsitektur, dimana client adalah perangkat yang menerima yang akan menampilkan dan menjalankan aplikasi (software komputer) dan server adalah perangkat yang menyediakan dan bertindak sebagai pengelola aplikasi, data, dan keamanannya, gambar seperti berikut:

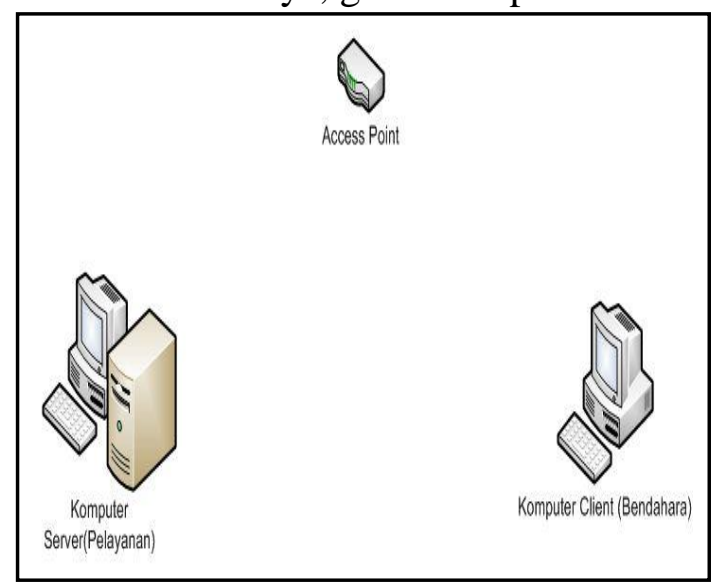


- Diagram konteks

Diagram konteks adalah diagram yang terdiri dari suatu proses dan menggambarkan ruang lingkup suatu sistem, gambar seperti berikut:

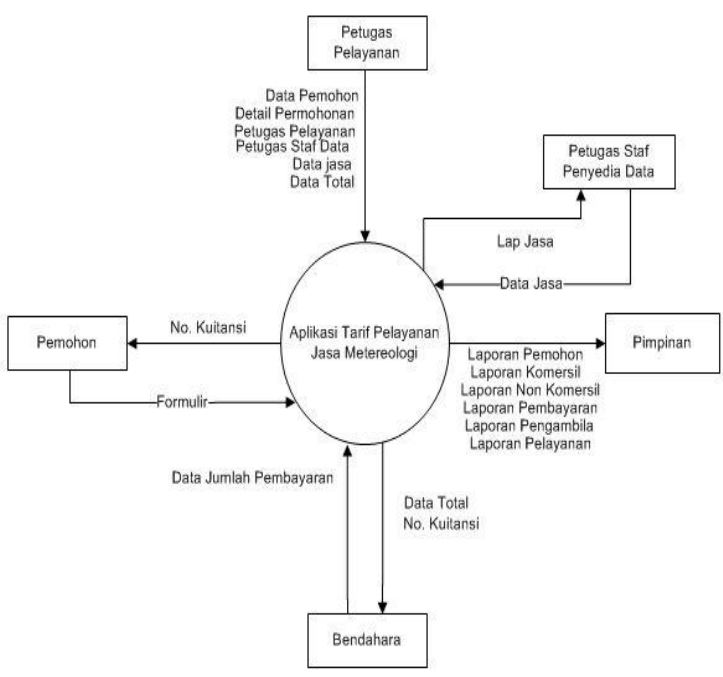

\section{- Data Flow Diagram (DFD)}

DFD menggambarkan penyimpanan data dan proses yang mentransformasikan data. DFD menunjukkan hubungan antara data dan proses pada sistem, gambar seperti berikut:

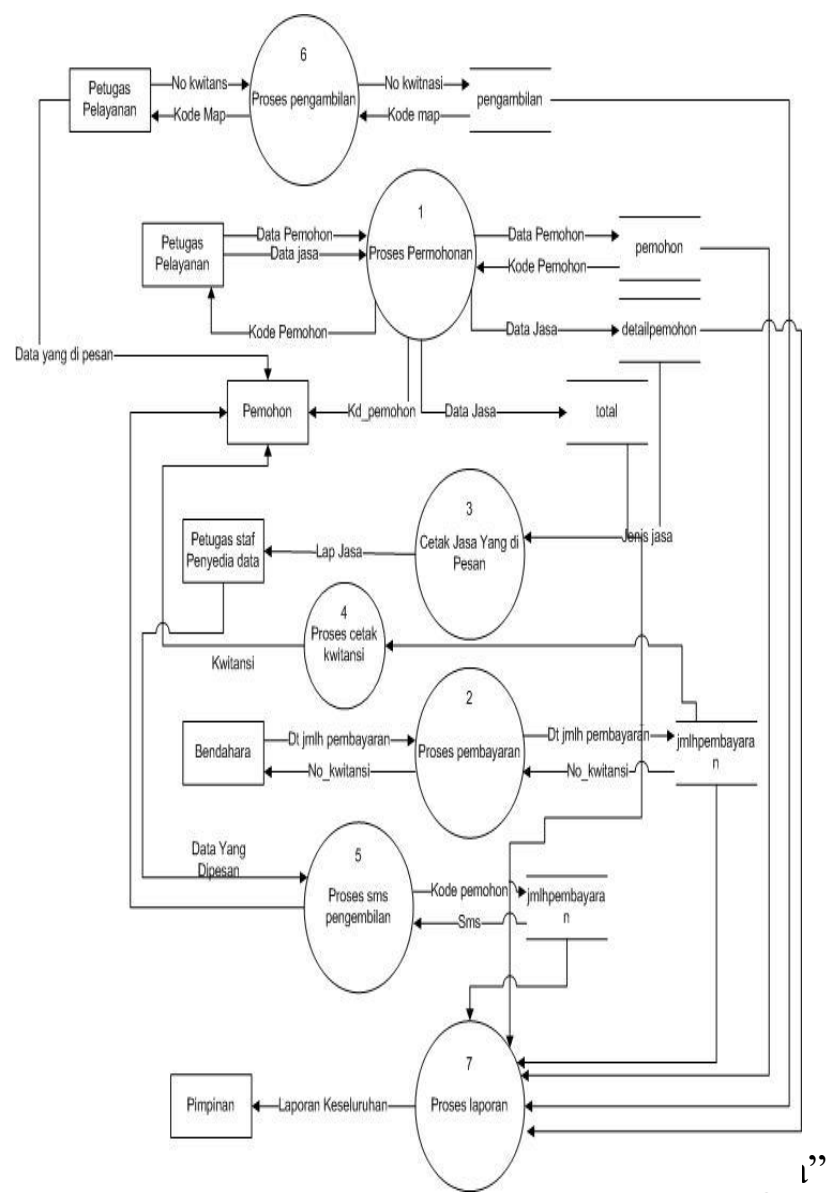

\section{- Relasi Antar Tabel}

Relasi antar tabel pada aplikasi tarif pelayanan jasa meteorologi berbasis client server adalah sebagai berikut:

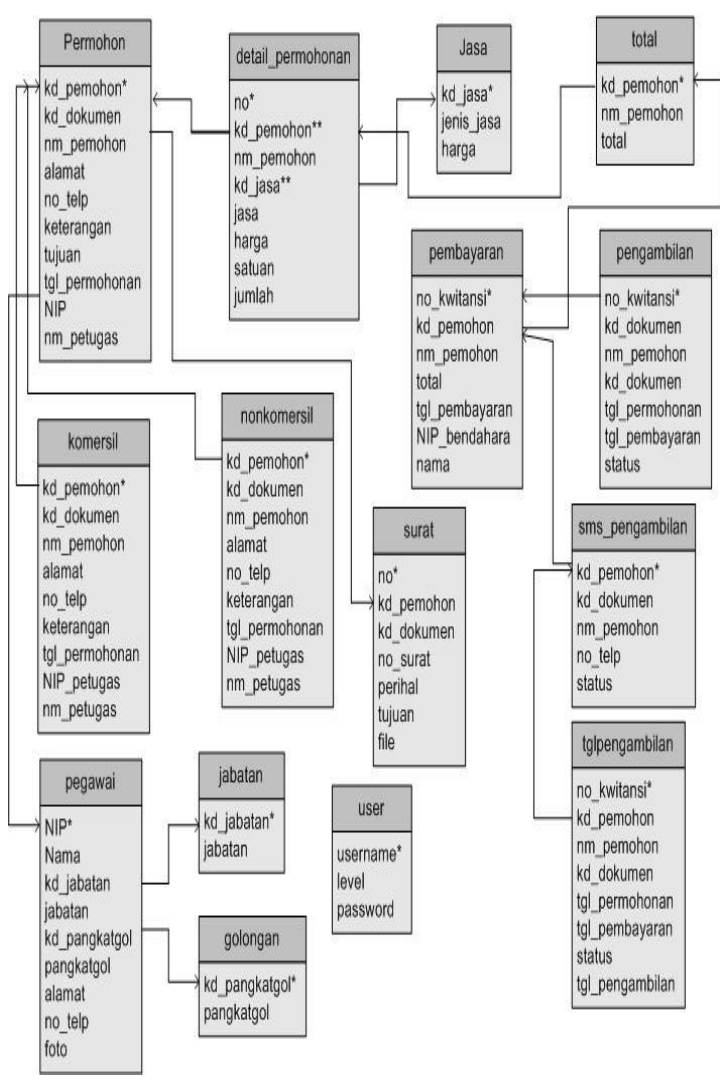

\section{Implementasi Sistem}

Form setting konfigurasi digunakan sebagai pengaturan koneksi antara komputer server ke database, dan komputer client ke komputer server, seperti gambar berikut:

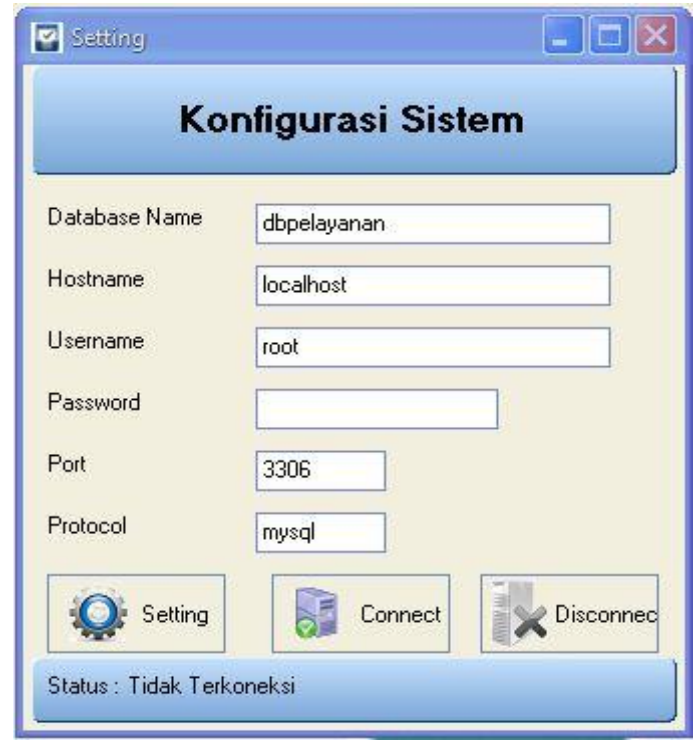


Menu utama adalah form yang dijadikan sebagai penghubung ke menu-menu yang lain.

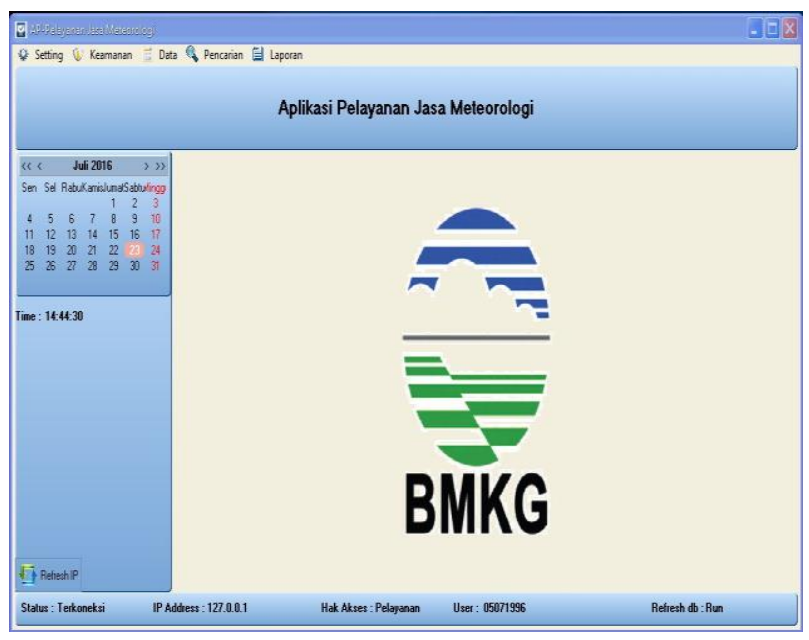

Gambar Form Menu Utama

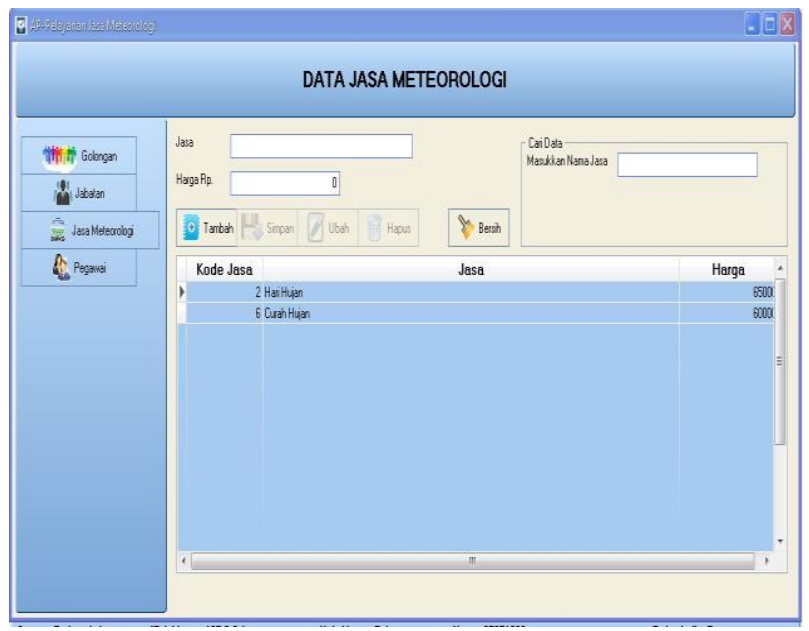

Gambar Form Data Jasa

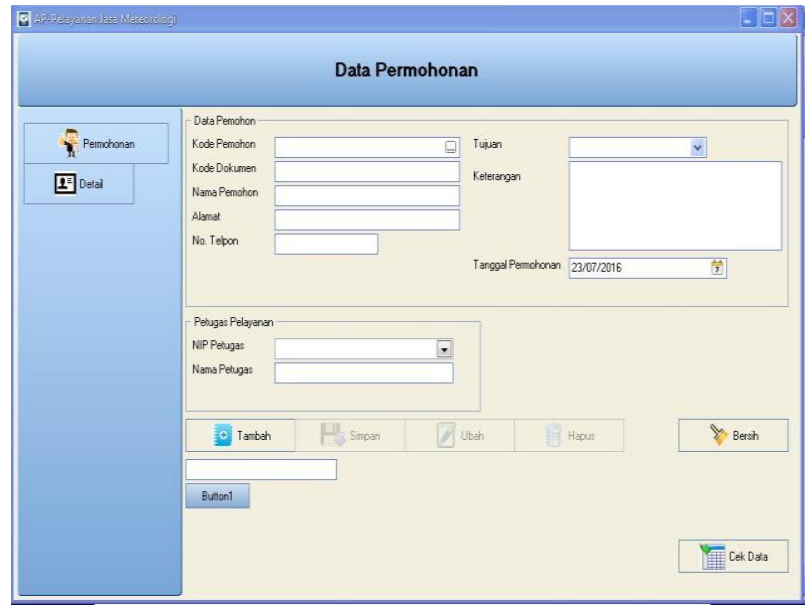

Gambar Form Data Pemohon

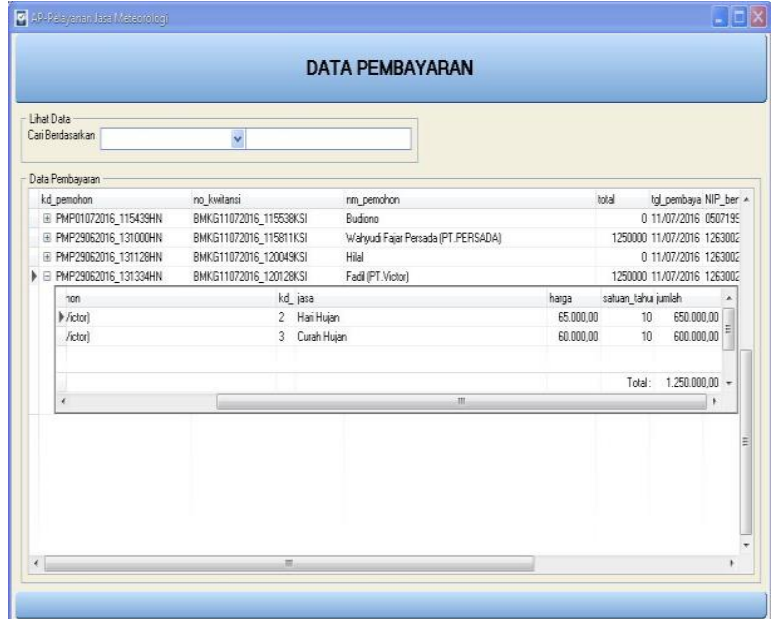

Form Data Pembayaran

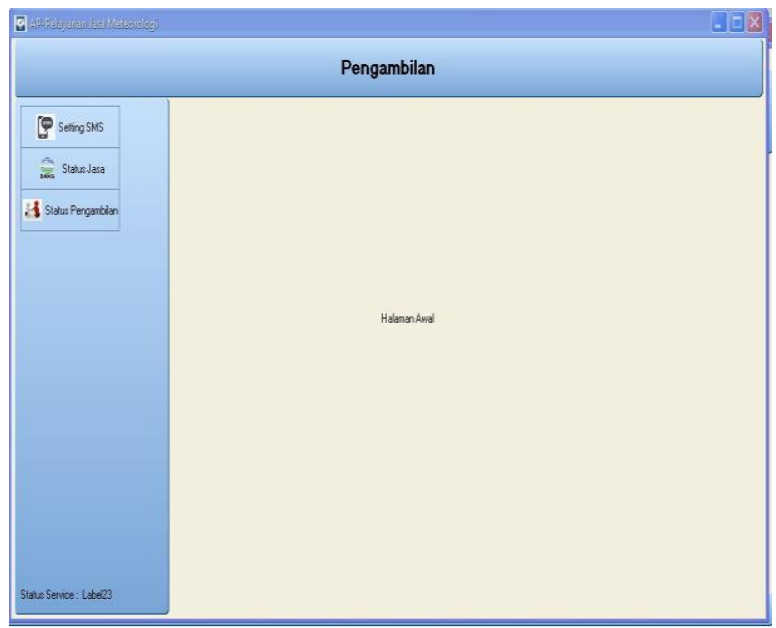

Form Data Pengambilan

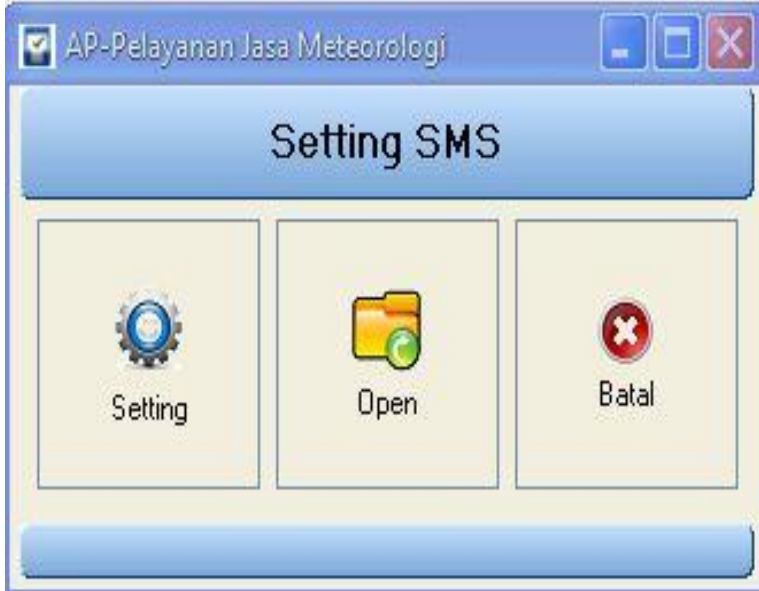

Gambar Form Setting SMS 


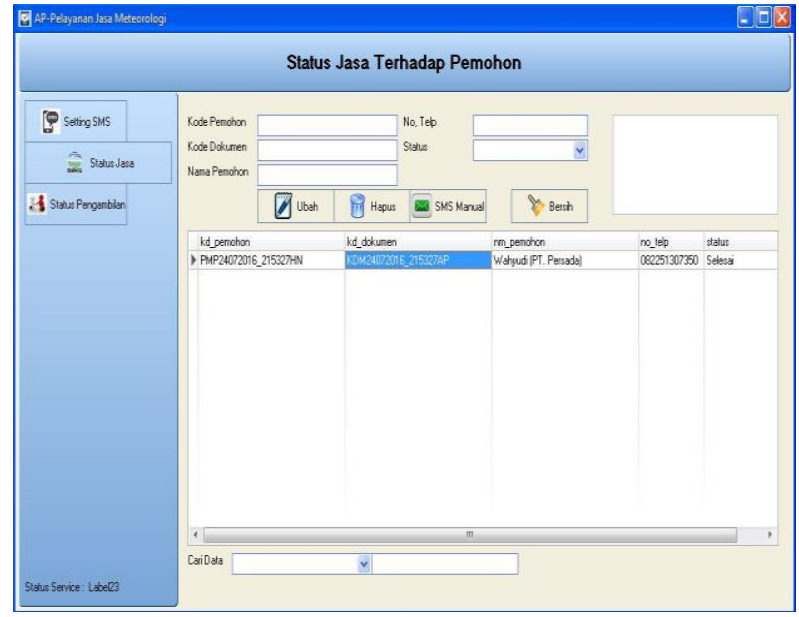

Gambar Form Pengambilan Tab Status Jasa

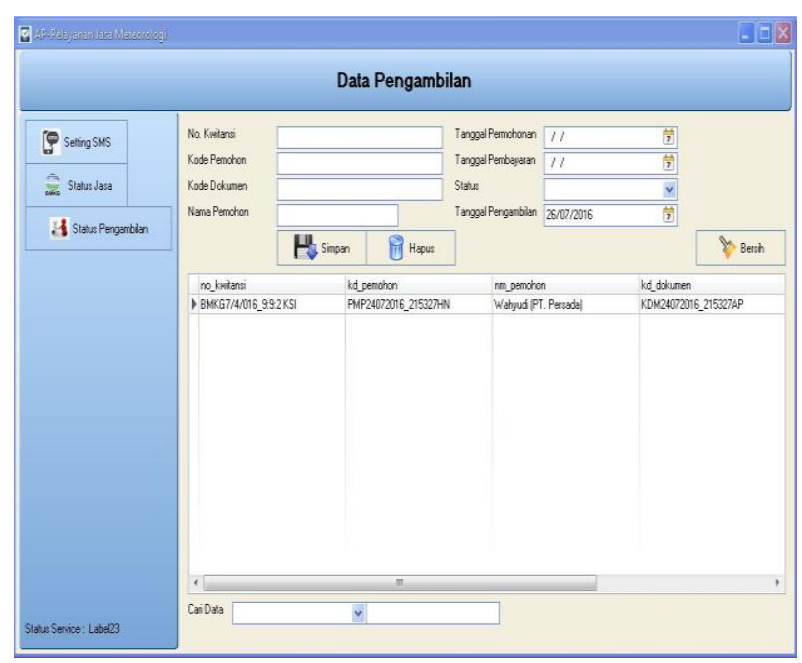

Gambar Form Pengambilan Data

(Data Sudah Selesai)

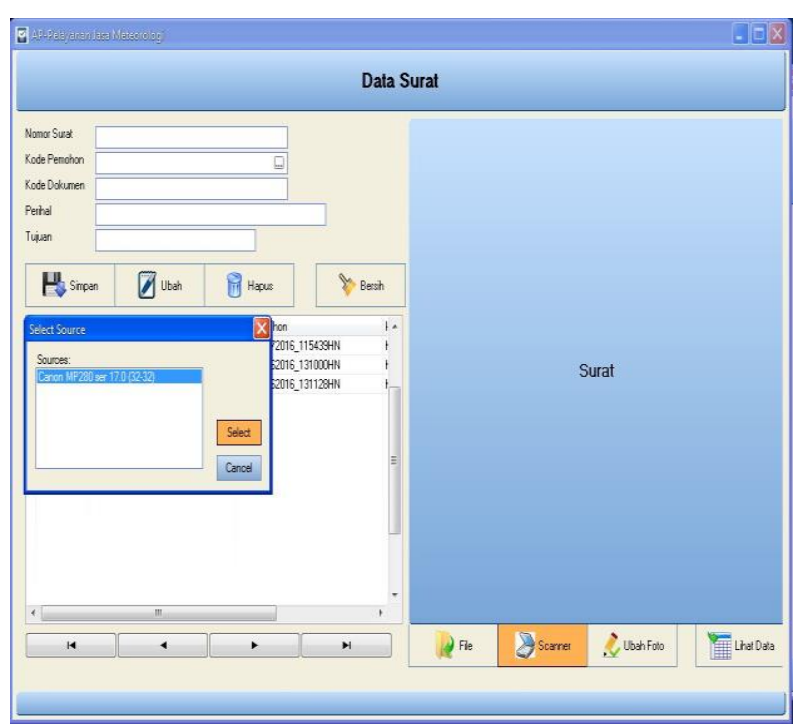

Gambar Form Surat

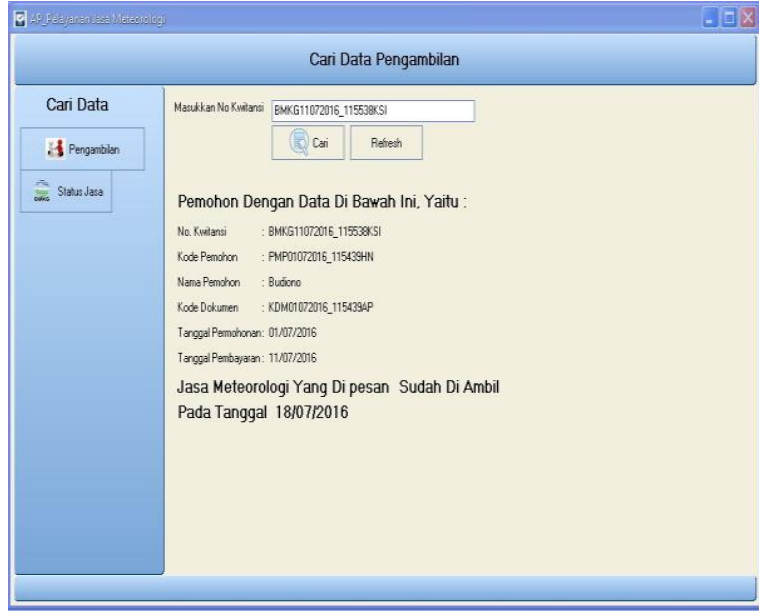

Gambar Form Cari Data Pengambilan

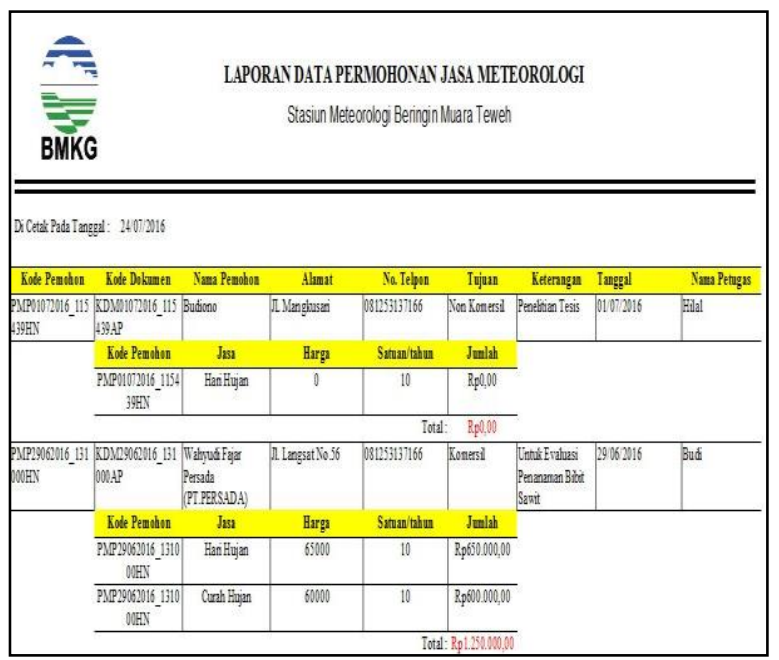

Gambar Laporan Data Pemohon

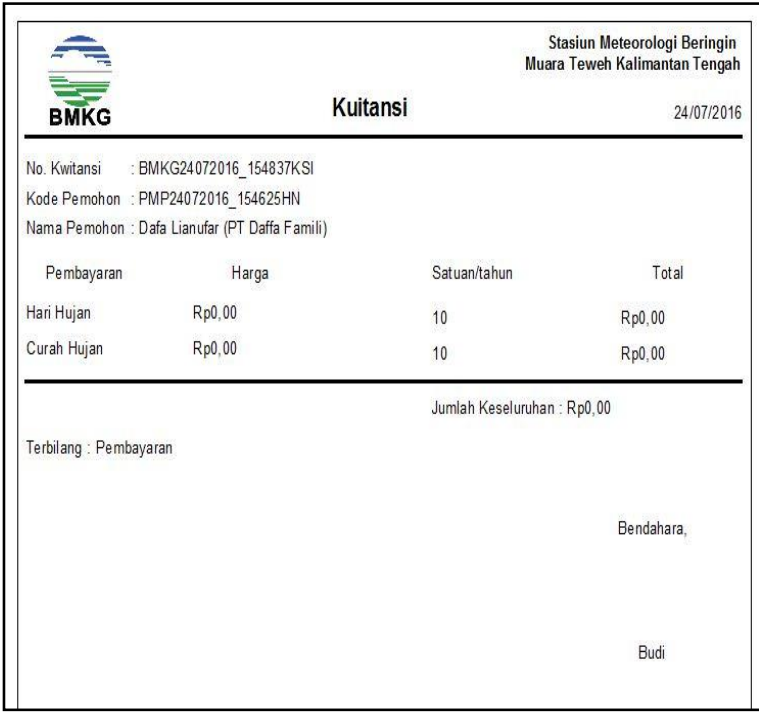

Gambar Laporan Kuitansi 


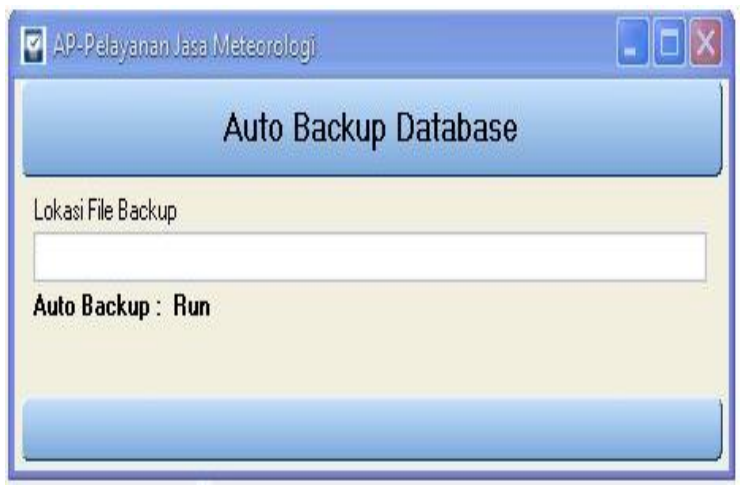

Gambar Auto Backup

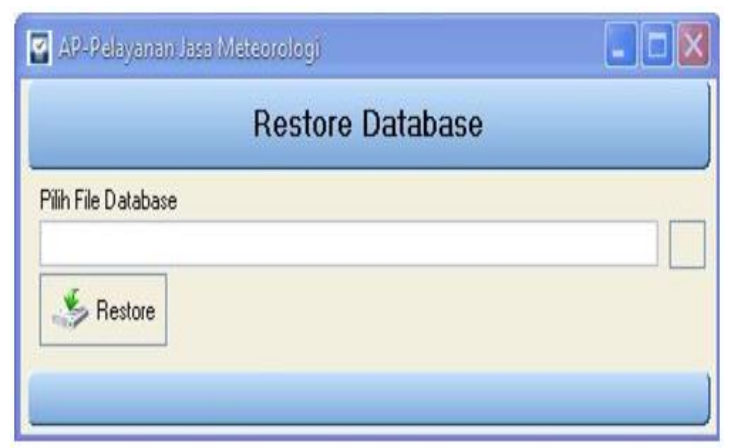

Gambar Restore Database

\section{PENUTUP}

\section{Kesimpulan}

Berdasarkan analisis dan pembahasan sistem yang telah dibuat, maka dapat ditarik kesimpulan sebagai berikut:

- Sistem yang sudah terkomputerisasi, dapat memberikan kemudahan dan mempercepat dalam proses pengelolaan, pelayanan dalam pemberian jasa meteorologi terhadap pemohon.

- Sistem pembuatan laporan yang terkomputerisasi memberikan informasi data yang akurat dan tingkat ketelitian lebih tinggi, sehingga kemungkinan kesalahan kecil.

- Sistem yang client server menjadikan adanya keterhubungan diantara dua bagian yaitu bagian pelayanan dan bendahara, sehingga mempercepat dalam proses pelayanan.

- Adanya fitur sms otomatis ke pemohon, memberikan kecepatan dalam pemberian informasi bahwa data yang dipesan selesai.

- Sistem yang sudah terkomputerisasi dapat memberikan keamanan dalam penyimpanan data (back up).

\section{Saran}

Terdapat beberapa saran yang berkaitan dengan pengembangan aplikasi, antara lain sebagai berikut :

- Buat sistem yang berbasis web.

- Fitur sms dapat dikembangkan menjadi dua arah

\section{DAFTAR PUSTAKA}

Antok, Supriyanto, 2009, Jurnal Pengembangan Sistem Informasi Pelayanan Jaminan Kesehatan Masyarakat dan Rekam Medik, Surabaya.

Arbie, 2004, Manajemen Database dengan MySQL. Yogyakarta: Andi.

Dian Novita, 2011, Jurnal Perancangan Sistem Informasi Pelayanan Medis di Puskesma Sungai 2 , Semarang.

\section{HM, J, 2005, Analisis \& Desain Sistem} Informasi . Jakarta: Eirlangga Publisher.

Mita, 2010, Pengenalan Borland Delphi 7, Semarang.

Parno, S.Kom., MMSI., 2010, Langkah langkah Dalam Pembuatan DataFlow Diagram, Surabaya 